\title{
On Hertz' electrical vibrations in air
}

\section{E. Sarasin \& L. De La Rive}

To cite this article: E. Sarasin \& L. De La Rive (1891) On Hertz' electrical vibrations in air, Philosophical Magazine Series 5, 31:190, 289-290, DOI: 10.1080/14786449108620107

To link to this article: http://dx.doi.org/10.1080/14786449108620107

$$
\text { 曲 Published online: } 08 \text { May } 2009 .
$$

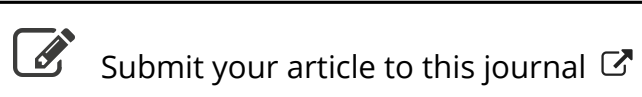

\footnotetext{
Џll Article views: 3
}

Q View related articles $\sqsubset$ 
translation in the direction of the discharge, we beg to make the following historical observations :-

1. When von Zahn investigated the spectral lines of a dischargetube, in one case in a direction at right angles to the axis, and then in the direction of the axis itself, the lines were not displaced, although he was able to distinguish even the $\frac{1}{40}$ of the distance of the $\mathrm{D}$ lines. This displacement would have corresponded to $\mathbf{a}$ velocity of one geographical mile in the direction of the axis *.

2. Preliminary experiments of Tait, in which the spectra of a tube containing bromide of carbon were found to be the same both when parallel and at right angles to the discharge-tube, showed that the velocity must be far greater, about 90 geographical miles in a second.

3. But that it can neither attain the value obtained by von Zahn, still less a higher one, follows from the experiments of $\mathbf{E}$. Wiedemann and $H$. Ebert $\dagger$, which were obtained both by the method of Fraunhofer's minima of the second class, as well as by the method of high interferences.

4. The method employed by Prof. Trowbridge, as he himself states, shows changes in the wave-length of $1 / 4000$; that used by Wiedemann and Ebert, of which, as well as of the other methods mentioned above, Professor Trowbridge makes no mention, shows a change of $1 / 834,000$ of the value. The latter is therefore about 200 times as sensitive as the former.

Erlangen, January 1891.

ON HERTZ'S ELECTRICAL VIBRATIONS IN AIR. BY E. SARASIN AND L. DE LA RIVE.

A very thin lead plate 2.95 metres broad and 2.8 metres high, was suspended vertically. The primary conductor was horizontal. and placed either at $5 \cdot 7$ or 9 metres distance from the lead plate, and parallel to it; its spark was formed in the perpendicular to the centre of the plate. The space in front of the lead plate was explored by means of a circular resonator, which was displaced along a divided scale on the normal to the lead plate. The scintilla at the break is, as observed by Hertz, stronger when the continuous part of the circuit in which the induction preponderates is in a loop, and the break is in a node, whereby for each node the break can be turned to or away from the reflecting lead plate. Close to the reflector is a node. With various primary conductors and resonators of $1,0.75,0.5,0.36,0.25$, and 0.20 metre in diameter, almost the same intermediate spaces were found as along wires. The velocity of propagation through air is thus essentially the same as with wires. In this case also the resonance is a multiple one;

* Wiedemann's 'Electricity,' vol, iv. p. 580.

† Wiedemann's Annalen, vol. xxxvi. p. 553, 1889. 
the existence of simultaneous, but different wave-lengths proceeding from the same primary conductor may be established; ouly in air are the limits much closer than in wires. In order to obtain clear results the dimensions of the primary conductors must here bear a given ratio to that of the resonator, which does not differ greatly from unity.

For circles of the diameter $2 \mathrm{R}$, the distance of the node in air $\mathrm{L}$, and in the wires $\mathrm{D}$, there was obtained :-

$$
\begin{array}{ccccc}
2 \mathrm{R} & \ldots & 0.26 \mathrm{~m} . & 0.36 & 0 \cdot 75 \\
\mathrm{~L} & \ldots & 1.1 .2-1.25 \mathrm{~m} . & \mathbf{1} \cdot 40-1.80 & 3 \cdot 00-3 \cdot 3 \\
\mathrm{D} & \ldots & 1.12 & 1.47 & 2 \cdot 96
\end{array}
$$

The waves in air are thus not at all, or but little, longer than in wires.-Archiv. de Genève, [3] x xii. p. 557 (1890); Beiblätter der Physik, vol. xiv. p. 1200 (1890).

\section{ON THE CONDUCTION OF ELECTRICITY BY THE VAPOURS OF HEATED SALTS. BY SVANTE ARRHENIUS.}

The author gives a long and important paper on this subject; the method of experimenting was to produce the vapour in the flame of a Bunsen-burner, and to measure the conductivity between two platinum wires placed at a given distance from each other. The various experimental precautions are fully described and discussed; the experiments extended to various classes of salts, and the author sums up his conclusions as follows.

The extremely fruitful bypothesis of van't Hoff, that matter in the form of gas and in that of dilute solution has perfectly analogous properties, has so far been established in the most brilliant manner; and with the aid of the laws of gases a light has been thrown on the nature of solutions, hitherto undreamed of. In the present paper I have followed the reverse way, and with a knowledge of the electrolytic properties of dilute solutions the same properties which bave hitherto been unknown have been demonstrated in gases. Hence there is a complete analogy in this respect between the two conditions of matter.-Wiedemann's Annalen, vol.xlii. p. 18 (1891).

\section{ELECTRICAL WAVES. BY ERNST LECHER.}

The author descrikes a new method of studying Hertz's phenomena. Instead of a resonator of the type employed by the latter, a Geissler tube is ustd. Two parallel wires of known self-induction terminate at one end in condenser-plates, which are charged in an oscillatory manner by a large Rubmkorf coil excited by storage-cells. Uf on the other ends of the parallel wires rests 